\title{
Health interventions for the reduction of hospital readmission within 30 days in clinical patients: An integrative review
}

\author{
Intervenções de saúde para redução da readmissão hospitalar em 30 dias em pacientes clínicos: \\ revisão integrativa \\ Intervenciones de salud para reducir el reingreso hospitalario en $\mathbf{3 0}$ días: una revisión integradora
}

Received: 12/31/2021 | Reviewed: 01/05/2022 | Accept: 01/15/2022 | Published: 01/17/2022

Aline Marques Acosta

ORCID: https://orcid.org/0000-0002-4816-6056 Universidade Federal do Rio Grande do Sul, Brazil E-mail: aline.acosta@gmail.com

Maria Alice Dias da Silva Lima

ORCID: https://orcid.org/0000-0002-3490-7335 Universidade Federal do Rio Grande do Sul, Brazil

E-mail: malice.dslima@gmail.com

Giselda Quintana Marques

ORCID: https://orcid.org/0000-0003-2567-4602 Prefeitura Municipal de Porto Alegre, Brazil E-mail: gqmarques@gmail.com

Amanda Pinto Abreu

ORCID: https://orcid.org/0000-0001-8901-8845 Centro Universitário Ritter dos Reis, Brazil E-mail: abreuamanda001@gmail.com

Amanda Xavier Sanseverino

ORCID: https://orcid.org/0000-0002-2441-5206 Universidade Federal do Rio Grande do Sul, Brazil E-mail: amandaxsan@gmail.com

Nelly Oelke

ORCID: https://orcid.org/0000-0002-1666-5360 University of British Columbia, Canada E-mail: nelly.oelke@ubc.ca

\begin{abstract}
Study with the objective of analysing the evidence available in the scientific literature on the interventions used to reduce hospital readmissions within 30 days in clinical patients who were discharged from the hospital to the home. An integrative review was carried out on the online Medical Literature Analysis and Retrieval System and Latin American and Caribbean Literature in Health Sciences databases. Intervention research, published between January 2009 and April 2020, in Portuguese, English and Spanish, was included. The sample consisted of 71 articles. The most frequently performed interventions were telephone contact after discharge (73.2\%), health education after discharge (71.8\%) and health education during hospitalization (67.6\%). Identification of readmission risk (12.9\%), home visits after discharge $(26.8 \%)$ and discharge planning $(28.2 \%)$ were the least mentioned. The interventions were performed predominantly by a multidisciplinary team $(39.5 \%)$. There was a significant reduction in readmissions in $50.7 \%$ of the studies. It was found that the interventions are aimed at preparing the patient during hospitalization for the return home and postdischarge monitoring to reinforce the care plans and clarify doubts, this important combination of different actions by the multiprofessional team impacts readmission rates.
\end{abstract}

Keywords: Patient readmission; Patient discharge; Continuity of patient care; Quality indicators, health care.

\section{Resumo}

Estudo com objetivo de analisar as evidências disponíveis na literatura científica sobre as intervenções de saúde utilizadas para a redução de readmissões hospitalares em até 30 dias em pacientes clínicos que tiveram alta do hospital para o domicílio. Foi realizada uma revisão integrativa nas bases de dados Medical Literature Analysis and Retrieval System on-line e Literatura Latino-americana e do Caribe em Ciências da Saúde. Foram incluídas pesquisas de intervenção, publicadas entre janeiro de 2009 a abril de 2020, em português, inglês e espanhol. A amostra foi composta de 71 artigos. As intervenções mais frequentemente realizadas foram contato telefônico após alta $(73,2 \%)$, educação em saúde após alta $(71,8 \%)$ e na internação $(67,6 \%)$. Identificação do risco de readmissão $(12,9 \%)$, visita domiciliar após alta $(26,8 \%)$ e planejamento de alta $(28,2 \%)$ foram as menos citadas. As intervenções foram realizadas predominantemente por equipe multiprofissional $(39,5 \%)$. Verificou-se redução significativa das readmissões em 50,7\% 
dos estudos. Constatou-se que as intervenções são voltadas à preparação do paciente durante a internação para o retorno ao domicílio e ao acompanhamento após a alta para reforçar os planos de cuidados e esclarecer dúvidas, sendo importante a combinação de diferentes ações pela equipe multiprofissional.

Palavras-chave: Readmissão do paciente; Alta do paciente; Continuidade da assistência ao paciente; Indicadores de qualidade em assistência à saúde.

\section{Resumen}

Este estudio tuvo como objetivo analizar la evidencia disponible en la literatura científica sobre las intervenciones de salud utilizadas para reducir los reingresos hospitalarios en 30 días en pacientes clínicos que fueron dados de alta del hospital al domicilio. Se realizó una revisión integradora en las bases de datos Medical Literature Analysis and Retrieval System on-line y Literatura Latinoamericana y del Caribe en Ciencias de la Salud. Se incluyeron investigaciones de intervención, publicadas entre enero de 2009 y abril de 2020, en portugués, inglés y español. La muestra estuvo formada por 71 artículos. Las intervenciones más frecuentes fueron el contacto telefónico tras el alta (73,2\%), la educación sanitaria tras el alta $(71,8 \%)$ y durante la hospitalización (67,6\%). La identificación del riesgo de reingreso (12,9\%), las visitas domiciliarias tras el alta $(26,8 \%)$ y la planificación del alta $(28,2 \%)$ fueron las menos mencionadas. Las intervenciones fueron realizadas predominantemente por un equipo multidisciplinario (39,5\%). Hubo una reducción significativa de los reingresos en el 50,7\% de los estudios. Se encontró que las intervenciones están orientadas a preparar al paciente durante la hospitalización para el regreso a casa y el seguimiento posterior al alta para reforzar los planes de atención y aclarar dudas, siendo importante la combinación de diferentes acciones por parte del equipo multidisciplinario.

Palabras clave: Readmisión del paciente; Alta del paciente; Continuidad de la atención al paciente; Indicadores de calidad de la atención de salud.

\section{Introduction}

Rate of hospital readmission has been considered an indicator of quality of health care (Neta et al., 2017, Tavares et al., 2020). It measures how many patients are readmitted to the hospital after they have been discharged. However, it lacks an accurate definition of the time interval from the initial hospitalization, although 30 days was the most frequently used in the studies (Fischer et al., 2012). The continual discussion of hospital readmissions is evident in the management of health systems, due to their impact on the patient outcomes and on the costs of the services. Despite the efforts at all levels of the system, readmissions remain prevalent, expensive and potentially avoidable (Conner et al., 2020).

A number of studies indicate that hospital readmission is influenced by individual and organizational factors that can be related to the care provided from admission to post-discharge (Tavares et al., 2020, Fischer et al., 2012). The individual factors involve aspects related to the patients and their health status (Tavares et al., 2020, Fischer et al., 2012), such as presence of chronic diseases, comorbidities, disease severity, socioeconomic status (Conner et al., 2020, Souza \& Peixoto, 2017), and patient's adherence to the therapy (Oscalices et al., 2019). The organizational factors include inadequate management of the comorbidities during hospitalization, errors in medication use, and failures in communication and in the post-discharge followup (Wiegmann et al., 2020).

A research study conducted in the United States identified that $26.9 \%$ of the readmissions are avoidable, with half of them representing gaps in care during the initial hospitalization. Various factors were associated with potentially preventable readmissions, the most important of which are failure to relay important information to outpatient health care professionals, premature discharge, lack of discussions about care goals with the patients, inadequate treatment of symptoms, inadequate monitoring for adverse effects or non-adherence to medications, follow-up appointments not scheduled, and patient's lack of awareness of whom to contact after discharge or when to resort to the emergency service (Auerbac et al., 2016).

Although not all readmissions are avoidable, it is understood that the use of different care transition strategies during hospitalization and at hospital discharge, as well as in the post-discharge period, may prevent readmissions (Conner et al., 2020, Lima et al., 2018). In a randomized clinical trial with heart failure patients, a multicomponent intervention was conducted, including self-care education during hospitalization, communication with primary health care providers for treatment continuity and post-discharge follow-up, where 37\% reduction was observed in the number of readmissions within 30 days (Huynh et al., 
2019). In Brazil, the occurrence of hospital readmission varies from $12.3 \%$ to $22 \%$ (Neta et al., 2017, Weber et al., 2019), a significant percentage that poses a challenge for cost management and affects the health system (Neta et al., 2017). These high rates signal the importance of discussing and implementing safe, evidence-based care transition strategies.

However, the Brazilian literature about interventions to reduce hospital readmission is scarce. The studies identified are focused on the profile of readmissions (Neta et al., 2017), on therapeutic adherence and readmission (Oscalices et al., 2019), on reviewing readmission in kidney transplantation (Tavares et al., 2020), and on care transition strategies at hospital discharge, with no focus on the reduction in the number of readmissions (Lima et al., 2018). Consequently, the need was identified to synthesize the results obtained in national and international research studies on interventions that reduce hospital readmissions, constituting a consistent and comprehensive scenario for the development of effective practices and policies. The objective of this study is to analyze the evidence available in the scientific literature on the health interventions used to reduce hospital readmissions within 30 days in clinical patients who were discharged from the hospital to their homes.

\section{Methodology}

This is an integrative review study that followed five stages: 1) identification of the problem; 2) search in the literature; 3) data evaluation; 4) data analysis; and 5) data presentation (Whittemore \& Knafl, 2005).

The PICO strategy (which represents Patient, Intervention, Comparison and Outcomes) was used to formulate the research question, where: P: clinical patients who were discharged from the hospital to their homes; I: health interventions to reduce hospital readmission; C: no intervention; and O: reduction in hospital readmission within 30 days after discharge. The following review question was elaborated: What is the scientific evidence on health interventions used to reduce hospital readmission within 30 days in clinical patients who were discharged from the hospital to their homes?

The data search was conducted in January 2019 and updated in April 2020 on the following databases: Medical Literature Analysis and Retrieval System on-line (MEDLINE via PubMed) and Latin American and Caribbean Literature in Health Sciences (Literatura Latino-Americana e do Caribe em Ciências da Saúde, LILACS).

A combination of the following Medical Subject Headings (MeSH) descriptors was used as search strategy: ("readmission" OR "hospital readmission" OR "patient readmission" OR "unplanned readmission*" OR "30 day readmission" OR "re-admission" OR "re-admit*") AND ("discharge planning” OR "patient discharge" OR "patient transfer" OR "care transition" OR "care transitions" OR "transition of care” OR "transitional care” OR "continuity of care" OR "follow-up" OR "patient education" OR "medication reconciliation" OR "communication" OR "patient care team") AND (planning OR intervention*) NOT (child* OR infant* OR pediatri* OR mental* OR obstetric*).

The eligibility criteria established were as follows: 1) articles from intervention research studies; 2) studies that had an Intervention Group (IG) and a Control Group (CG); 3) studies whose outcome is hospital readmission within 30 days; 4) studies whose population is clinical patients over 18 years old and discharged from hospital units to their homes; 5) full text available articles on the selected databases, published from January 2009 to April 2020; 6) articles written in Portuguese, English or Spanish.

Theses, dissertations and review articles were excluded, as well as qualitative, methodological and protocol studies, reflection and/or theoretical articles and those from the grey literature. Articles focusing on war veterans and on palliative, surgical, oncological, rheumatology, obstetric, gynecological, psychiatric and pediatric care were excluded because of its specificities.

The references found were forwarded to the EndNote ${ }^{\circledR}$ bibliography manager software program. Duplicate articles were excluded. Study selection was performed independently by two reviewers, and cases of disagreement were solved by consensus 
in a meeting between the reviewers. A form containing the eligibility criteria was elaborated to select the articles. The papers included were read in full and a descriptive analysis of the characteristics of the studies was performed. For data extraction, an Excel spreadsheet was used to record main information of the studies, such as authors, year, language, title, objectives, design, level of evidence, study locus and population, sample size, health professional who performed the intervention, duration of intervention, interventions tested, and main results at readmission within 30 days.

The levels of evidence of the studies were assessed as described in the literature (Melnyk \& Fineout-Overholt, 2015).

The data analysis of the integrative review was elaborated in the descriptive manner. The components used in the studies included were classified into nine intervention categories, which were identified by the following codes: Identification of Readmission Risk (IRR), Discharge Planning (DP), Education in Health during Hospitalization (EHH), Education in Health after Discharge (EHD), Medication Reconciliation (MR), Communication with Health Services (CHS), Outpatient Follow-up after Discharge (OFD), Phone Contact after Discharge (PCD), and Post-discharge Home Visit (PHV).

\section{Results}

Initially, 2,043 articles were identified in the databases. For selection of the studies, the titles were read and 422 articles were screened. Then, the abstracts were read and 178 were assessed for eligibility. Upon reading the full text articles, the sample consisted of 71, as shown in the flowchart (Figure 1).

Figure 1. Flow diagram corresponding to the search in the literature. Porto Alegre/Brazil, 2021.

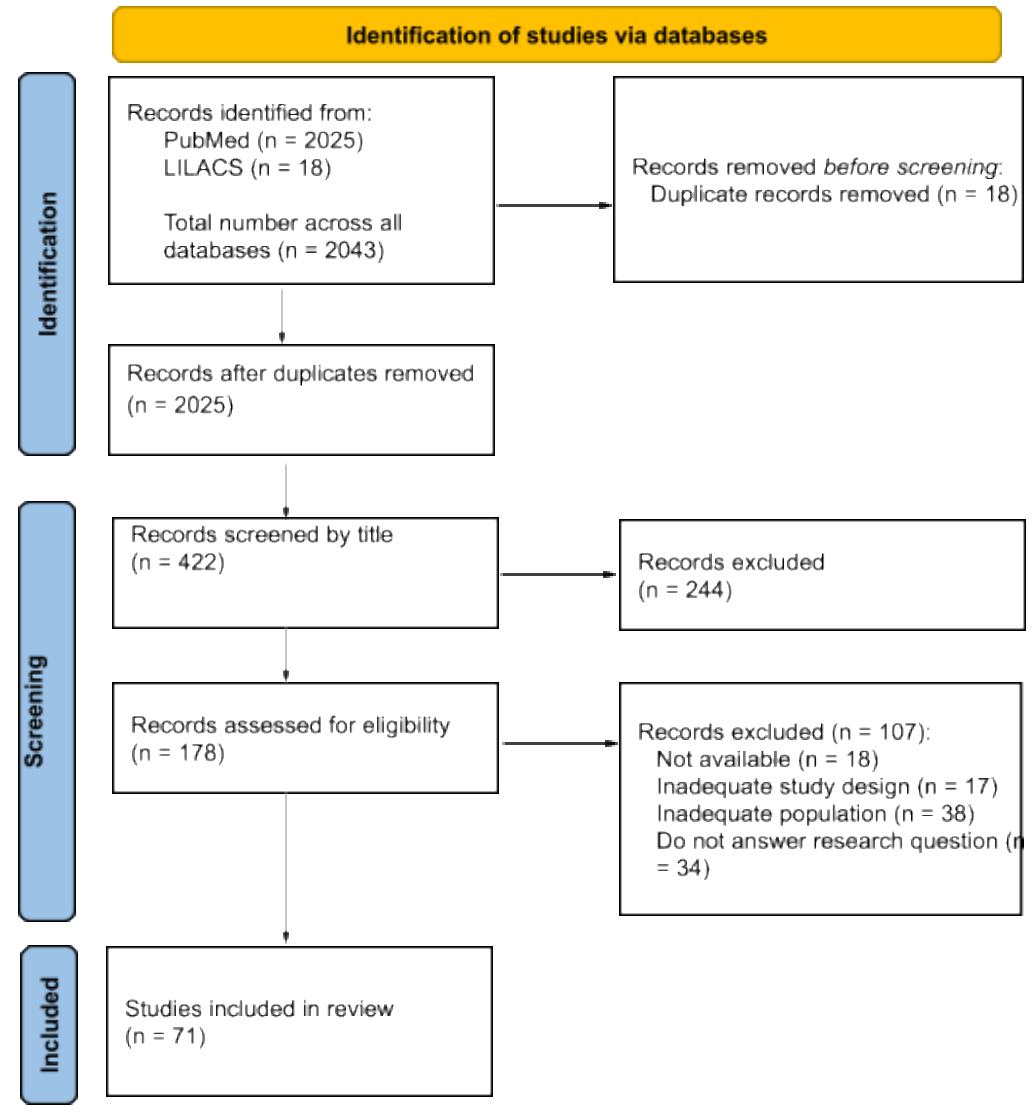

Sources: Authors. 
All the studies selected were written in English, with the United States as the country with the highest number of publications. The majority (53.5\%) were published from 2013 to 2016 . The most prevalent methodological designs were randomized clinical trials, cohort studies and quasi-experimental studies. Regarding the level of evidence of the publications, $29.6 \%$ were Level $02 ; 32.4 \%$, Level 03; and 38\%, Level 04. It was verified that $66.2 \%$ of the studies were focused on specific populations, such as seniors or people with heart or respiratory diseases. The interventions were predominantly conducted by a multi-professional team, pharmacists and nurses. Table 1 synthesizes the characteristics of the studies.

Table 1 - Main characteristics of the studies. Porto Alegre, 2021.

\begin{tabular}{|c|c|}
\hline Characteristic & Articles $(n=71)$ \\
\hline \multicolumn{2}{|l|}{ Type of study (Level of Evidence) } \\
\hline Randomized Clinical Trial (LE 02) & $19(26.8 \%)$ \\
\hline Randomized, controlled and prospective (LE 02) & $2(2.8 \%)$ \\
\hline Quasi-experimental (LE 03) & $12(16.9 \%)$ \\
\hline Pre-post Intervention (LE 03) & $4(5.6 \%)$ \\
\hline Prospective (LE 03) & $7(9.9 \%)$ \\
\hline Cohort (04) & $19(26.8 \%)$ \\
\hline Retrospective and descriptive (LE 04) & $5(7.0 \%)$ \\
\hline Observational (LE 04) & $2(2.8 \%)$ \\
\hline Case-control (LE 04) & $1(1.4 \%)$ \\
\hline \multicolumn{2}{|l|}{ Year of publication } \\
\hline From 2009 to 2012 & $6(8.5 \%)$ \\
\hline From 2013 to 2016 & $38(53.5 \%)$ \\
\hline From 2017 to 2020 & $27(38.0 \%)$ \\
\hline \multicolumn{2}{|l|}{ Country where the study was conducted } \\
\hline United States & $49(69.0 \%)$ \\
\hline Canada & $7(9.9 \%)$ \\
\hline Singapore & $3(4.2 \%)$ \\
\hline Denmark & $2(2.8 \%)$ \\
\hline United Kingdom & $3(4.2 \%)$ \\
\hline Brazil & $1(1.4 \%)$ \\
\hline Others & $6(8.4 \%)$ \\
\hline \multicolumn{2}{|l|}{ Study population } \\
\hline Adults in general & $24(33.8 \%)$ \\
\hline Elders & $9(12.7 \%)$ \\
\hline Patients with some heart disease & $18(25.3 \%)$ \\
\hline Patients with some respiratory disease & $7(9.9 \%)$ \\
\hline Others & $13(18.3 \%)$ \\
\hline \multicolumn{2}{|l|}{ Professionals who performed the intervention } \\
\hline Multi-professional team & $28(39.5 \%)$ \\
\hline Nurse & $9(12.7 \%)$ \\
\hline Pharmacist & $25(35.2 \%)$ \\
\hline Social worker & $2(2.8 \%)$ \\
\hline Physician & $1(1.4 \%)$ \\
\hline Other & $2(2.8 \%)$ \\
\hline Not reported & $4(5.6 \%)$ \\
\hline
\end{tabular}

LE: level of evidence. Sources: Authors.

Most of the studies had interventions with two or more components, resulting in a variety of strategies, where there may be multiple components present in a single article (Chart 1). 
Chart 1 - Synthesis of the interventions performed in the studies. Porto Alegre, 2021.

\begin{tabular}{|c|c|c|}
\hline Intervention & Description & Frequency n (\%) \\
\hline $\begin{array}{l}\text { Identification of the } \\
\text { Readmission Risk }\end{array}$ & $\begin{array}{l}\text { - Screening of patients at readmission risk through validated instruments (such } \\
\text { as the LACE Index and the Elders Risk Assessment index), predictive } \\
\text { models in software programs, or a tool specifically designed for the } \\
\text { intervention; } \\
\text { - Prioritization of the intervention to patients at risk for readmission. }\end{array}$ & $9(12.9 \%)$ \\
\hline Discharge Planning & $\begin{array}{l}\text { - Development of discharge planning during hospitalization, generally in } \\
\text { charge of the multi-professional team under the coordination of a specific } \\
\text { professional (nurse, pharmacist, etc.); } \\
\text { - Elaboration of an individualized plan, considering psychosocial and health } \\
\text { issues, adapted to the individual needs and using institutional tools or } \\
\text { software programs; } \\
\text { - Provision of the discharge plan, report or letter in printed format to the } \\
\text { patient and/or family member. }\end{array}$ & $20(28.2 \%)$ \\
\hline $\begin{array}{c}\text { Education in Health } \\
\text { during Hospitalization }\end{array}$ & $\begin{array}{l}\text { - Conduction of education in health activities during hospitalization by } \\
\text { transition nurses, pharmacists and/or physicians; } \\
\text { - Education in health focused on medication use, life habits (diet, physical } \\
\text { exercise and smoking cessation) and management of symptoms after } \\
\text { discharge; } \\
\text { - Detailed explanation of the indications, benefits, duration and therapeutic } \\
\text { goals, as well as dose, schedule, storage and possible drug-related adverse } \\
\text { events; } \\
\text { - Use of a standardized script or checklist to provide guidelines during } \\
\text { hospitalization; } \\
\text { - Delivery of educational material to the patient and family member containing } \\
\text { information about post-discharge care measures. }\end{array}$ & $48(67.6 \%)$ \\
\hline $\begin{array}{l}\text { Education in Health } \\
\text { after Discharge }\end{array}$ & $\begin{array}{l}\text { - Conduction of education in health activities after discharge, by means of } \\
\text { consultations, phone contacts or home visits; } \\
\text { - Use of a standardized script or checklist to provide guidelines after discharge; } \\
\text { - Reinforcement on the guidelines about the necessary home care measures and } \\
\text { clarification of doubts; } \\
\text { - Delivery of educational material to the patient and family member containing } \\
\text { information about post-discharge care measures; } \\
\text { - Participation in an interprofessional program that offers classes about the } \\
\text { disease and post-discharge care measures. }\end{array}$ & $51(71.8 \%)$ \\
\hline $\begin{array}{c}\text { Medication } \\
\text { Reconciliation }\end{array}$ & $\begin{array}{l}\text { - Medication reconciliation performed by a pharmacist, evaluating medications } \\
\text { used prior to admission and after discharge; } \\
\text { - Multi-professional rounds to discuss inconsistencies in the drug treatment; } \\
\text { - Use of a system to document and monitor medication reconciliation; } \\
\text { - Risk stratification during reconciliation, based on a literacy in health } \\
\text { assessment and on patient's adherence to the medication; } \\
\text { - Delivery of educational material to the patient containing information about } \\
\text { the medications in use. }\end{array}$ & $32(45.1 \%)$ \\
\hline $\begin{array}{l}\text { Communication with } \\
\text { Health Services }\end{array}$ & $\begin{array}{l}\text {-Patient's referral to care with specialists or at health services after hospital } \\
\text { discharge, such as primary health care units, rehabilitation services and social } \\
\text { community services, according to the patient's needs. } \\
\text { - Scheduling of the appointment in the health unit for after discharge; } \\
\text { - Notification of the patients' hospitalization to the service that will care for } \\
\text { them after discharge via an integrated information system, text message, } \\
\text { voicemail, email or letter; } \\
\text { - Forwarding of the discharge summary, care plan or brief description of the } \\
\text { transition care measures for professionals or services that will provide care } \\
\text { continuity after discharge. }\end{array}$ & $32(45.1 \%)$ \\
\hline
\end{tabular}




\begin{tabular}{|c|c|c|}
\hline $\begin{array}{l}\text { Outpatient Follow-up } \\
\text { after Discharge }\end{array}$ & $\begin{array}{l}\text { - Conduction of follow-up appointments, between two and ten days after } \\
\text { discharge, for disease management, monitoring of adverse events and } \\
\text { provision of guidelines for adherence to the treatment; } \\
\text { - Use of software programs to schedule and control follow-up appointments. }\end{array}$ & $24(33.8 \%)$ \\
\hline $\begin{array}{c}\text { Phone Contact after } \\
\text { Discharge }\end{array}$ & $\begin{array}{l}\text { - Telephone call made from two to } 30 \text { days after discharge for clinical } \\
\text { reassessment, guidance on home care, treatment difficulties, and resumption of } \\
\text { daily activities, clarification of doubts, and verification of appointment } \\
\text { scheduling; } \\
\text { - Follow-up appointment by telephone after discharge conducted by } \\
\text { pharmacists; } \\
\text { - Use of instruments to guide the telephone calls after discharge, such as scripts, } \\
\text { checklists and questionnaires; } \\
\text { - Full-time availability of telephone lines for communication between patients } \\
\text { and health teams; } \\
\text { - Use of an interactive system with smartphone alerts or messages for } \\
\text { communication between patients and health teams. }\end{array}$ & $52(73.2 \%)$ \\
\hline $\begin{array}{c}\text { Post-discharge Home } \\
\text { Visit }\end{array}$ & $\begin{array}{l}\text { - Conduction of a home visit for clinical reassessment, assessment of adherence } \\
\text { to the treatment, guidance about home care, clarification of doubts and } \\
\text { adjustments in the care plan; } \\
\text { - Assessment of the patient's need for social support; } \\
\text { - Provision of equipment and medications for home use; } \\
\text { - Use of instruments to guide the post-discharge home visits, such as protocols } \\
\text { and checklists; } \\
\text { - Visits to all the intervention patients or only to those at a higher risk of } \\
\text { readmission or with more difficulties in the treatment; } \\
\text { - Presence of a transition professional in the visits to the patient. }\end{array}$ & $19(26.8 \%)$ \\
\hline
\end{tabular}

Source: Authors.

The most frequently used components in the studies for the reduction in the number of readmissions were Phone Contact after Discharge, Education in Health after Discharge and Education in Health during Hospitalization. The least frequent components were Identification of Readmission Risk, Post-discharge Home Visit and Discharge Planning. Chart 2 shows the components performed and the outcome of hospital readmission of the studies analyzed.

A significant reduction in the number of readmissions within 30 days after discharge was verified in $50.7 \%$ of the studies. Among the randomized clinical trials, $63.2 \%$ obtained significantly lower readmission rates in the intervention groups when compared to the control groups. Of the interventions performed by nurses, $66.6 \%$ obtained significant improvements in the outcome.

Chart 2 - Interventions performed and outcome of hospital readmission of the studies included in the integrative review. Porto Alegre, 2021.

\begin{tabular}{|c|c|c|c|c|c|c|c|c|c|c|c|}
\hline \multirow[b]{2}{*}{$\begin{array}{c}\text { Methodological design of the articles } \\
\text { and levels of evidence }\end{array}$} & \multicolumn{10}{|c|}{ Code of the interventions performed } & \multirow{2}{*}{$\begin{array}{l}\text { Significant } \\
\text { reduction in } \\
\text { readmission* }\end{array}$} \\
\hline & IRR & DP & EHH & EHD & MR & CHS & OFD & PCD & PHV & Other & \\
\hline \multicolumn{12}{|l|}{ Randomized Clinical Trial (LE 02) } \\
\hline Altfeld et al. (2013) & & $\mathrm{x}$ & & & & $\mathrm{x}$ & $\mathrm{x}$ & $\mathrm{x}$ & & & No \\
\hline Balaban et al. (2015) & & $\mathrm{x}$ & & & & $\mathrm{X}$ & $\mathrm{x}$ & $\mathrm{x}$ & & & No \\
\hline Bell et al. (2016) & & & $\mathrm{x}$ & $\mathrm{x}$ & $\mathrm{X}$ & $\mathrm{x}$ & & $\mathrm{x}$ & & & No \\
\hline Benzo et al. (2016) & & & $\mathrm{x}$ & $\mathrm{x}$ & & & & $\mathrm{x}$ & $\mathrm{X}$ & & Yes \\
\hline Bonetti et al. (2018) & & $\mathrm{x}$ & $\mathrm{x}$ & $\mathrm{x}$ & $\mathrm{X}$ & & & $\mathrm{x}$ & & & No \\
\hline Davis et al. (2012) & & & $\mathrm{x}$ & $\mathrm{x}$ & & & & $\mathrm{x}$ & & & No \\
\hline Deek et al. (2017) & & & $\mathrm{x}$ & & & & & & & & Yes \\
\hline Dhalla et al. (2014) & $\mathrm{x}$ & & $\mathrm{x}$ & $\mathrm{x}$ & & $\mathrm{x}$ & $\mathrm{x}$ & $\mathrm{x}$ & $X$ & & No \\
\hline Farris et al. (2014) & & & $\mathrm{x}$ & $\mathrm{x}$ & $\mathrm{X}$ & $\mathrm{x}$ & & $\mathrm{x}$ & & & No \\
\hline Graabaek et al. (2019) & & & $\mathrm{x}$ & & $\mathrm{X}$ & & & & & & No \\
\hline
\end{tabular}


Research, Society and Development, v. 11, n. 2, e2011225273, 2022

(CC BY 4.0) | ISSN 2525-3409 | DOI: http://dx.doi.org/10.33448/rsd-v11i2.25273

\begin{tabular}{|c|c|c|c|c|c|c|c|c|c|c|c|}
\hline Huynh et al. (2019) & & & $\mathrm{x}$ & $\mathrm{x}$ & & $\mathrm{x}$ & & $\mathrm{x}$ & $\mathrm{X}$ & $\mathrm{x}$ & Yes \\
\hline Jennings et al. (2015) & & & $\mathrm{x}$ & $\mathrm{x}$ & & $\mathrm{x}$ & & $\mathrm{x}$ & & & No \\
\hline Johnson-Warrington et al. (2016) & & & $\mathrm{x}$ & $\mathrm{x}$ & & & & $\mathrm{x}$ & & & No \\
\hline Lee et al. (2015) & $\mathrm{x}$ & & & $\mathrm{x}$ & & $\mathrm{x}$ & & $\mathrm{x}$ & $\mathrm{X}$ & & No \\
\hline Linden et al. (2014) & & $\mathrm{x}$ & $\mathrm{x}$ & $\mathrm{x}$ & $\mathrm{X}$ & $\mathrm{x}$ & $\mathrm{x}$ & $\mathrm{x}$ & & & No \\
\hline Low et al. (2017) & $\mathrm{x}$ & $\mathrm{x}$ & $\mathrm{x}$ & $\mathrm{x}$ & $\mathrm{X}$ & $\mathrm{x}$ & $\mathrm{x}$ & $\mathrm{x}$ & $\mathrm{X}$ & & Yes \\
\hline Riegel et al. (2016) & & & & $\mathrm{x}$ & & & & $\mathrm{x}$ & $\mathrm{X}$ & & Yes \\
\hline Soong et al. (2014) & & & $\mathrm{x}$ & $\mathrm{x}$ & & & & $\mathrm{x}$ & & & No \\
\hline Thygesen et al. (2015) & $\mathrm{x}$ & & & $\mathrm{x}$ & & $\mathrm{x}$ & $\mathrm{x}$ & & $\mathrm{X}$ & & No \\
\hline \multicolumn{12}{|l|}{ Prospective and controlled (LE 02) } \\
\hline Haag et al. (2016) & $\mathrm{x}$ & & & $\mathrm{x}$ & & & & $\mathrm{x}$ & & & No \\
\hline Hawes et al. (2014) & & $\mathrm{x}$ & & $\mathrm{x}$ & $\mathrm{X}$ & & $\mathrm{x}$ & & & & Yes \\
\hline \multicolumn{12}{|l|}{ Quasi-experimental (LE 03) } \\
\hline Amarasingham et al. (2013) & & $\mathrm{X}$ & $\mathrm{x}$ & & & & $\mathrm{x}$ & $\mathrm{x}$ & & & Yes \\
\hline Bhatt et al. (2017) & & & $\mathrm{x}$ & & & $\mathrm{x}$ & $\mathrm{x}$ & $\mathrm{x}$ & & & No \\
\hline Bowles et al. (2015) & $\mathrm{x}$ & $\mathrm{X}$ & & & & $\mathrm{x}$ & & & & & Yes \\
\hline Dedhia et al. (2009) & & $\mathrm{X}$ & $\mathrm{x}$ & & $\mathrm{x}$ & $\mathrm{x}$ & & & & & Yes \\
\hline Graham et al. (2012) & $\mathrm{x}$ & & & $\mathrm{x}$ & & & & $\mathrm{x}$ & & & Yes \\
\hline Kripalani et al. (2019) & & $\mathrm{X}$ & $\mathrm{x}$ & $\mathrm{x}$ & $\mathrm{x}$ & & & $\mathrm{x}$ & & $\mathrm{x}$ & Yes \\
\hline Morales et al. (2018) & & & $\mathrm{x}$ & $\mathrm{x}$ & & & & & $\mathrm{X}$ & & Yes \\
\hline Odeh et al. (2019) & & & & $\mathrm{x}$ & & $\mathrm{x}$ & & $\mathrm{x}$ & & & Yes \\
\hline Ohuabunwa et al. (2013) & & $\mathrm{X}$ & $\mathrm{x}$ & $\mathrm{x}$ & & $\mathrm{x}$ & & $\mathrm{x}$ & $\mathrm{X}$ & & No \\
\hline Smith et al. (2016) & & & $\mathrm{x}$ & & $\mathrm{x}$ & $\mathrm{x}$ & & & & & No \\
\hline Voss et al. (2011) & & $\mathrm{X}$ & $\mathrm{x}$ & $\mathrm{x}$ & & & & $\mathrm{x}$ & $\mathrm{X}$ & & Yes \\
\hline Walker et al. (2009) & & $\mathrm{X}$ & $\mathrm{x}$ & $\mathrm{x}$ & $\mathrm{x}$ & $\mathrm{x}$ & & $\mathrm{x}$ & & & No \\
\hline \multicolumn{12}{|l|}{ Pre-post Intervention (LE 03) } \\
\hline Garnier et al. (2018) & & & $\mathrm{x}$ & $\mathrm{x}$ & $\mathrm{x}$ & $\mathrm{x}$ & $\mathrm{x}$ & $\mathrm{x}$ & $\mathrm{X}$ & $\mathrm{x}$ & No \\
\hline Johnson et al. (2016) & $\mathrm{x}$ & & $\mathrm{x}$ & $\mathrm{x}$ & & & $\mathrm{x}$ & & $X$ & $\mathrm{x}$ & Yes \\
\hline Verhaegh et al. (2014) & & $\mathrm{X}$ & $\mathrm{x}$ & & $\mathrm{x}$ & & $\mathrm{x}$ & & & & No \\
\hline Xiang et al. (2019) & & & & & & $\mathrm{x}$ & & $\mathrm{x}$ & & & Yes \\
\hline \multicolumn{12}{|l|}{ Prospective (LE 03) } \\
\hline Budiman et al. (2016) & & $\mathrm{X}$ & $\mathrm{x}$ & $\mathrm{x}$ & $\mathrm{x}$ & & & $\mathrm{x}$ & & & No \\
\hline Murphy et al. (2019) & & & $\mathrm{x}$ & $\mathrm{x}$ & $\mathrm{x}$ & $\mathrm{x}$ & $\mathrm{x}$ & $\mathrm{x}$ & & & No \\
\hline Rafferty et al. (2016) & & & $\mathrm{x}$ & & $\mathrm{x}$ & & $\mathrm{x}$ & $\mathrm{x}$ & & & Yes \\
\hline Sales et al. (2013) & & & $\mathrm{x}$ & $\mathrm{x}$ & & $\mathrm{x}$ & $\mathrm{x}$ & $\mathrm{x}$ & & & Yes \\
\hline Sarangarm et al. (2013) & & & $\mathrm{x}$ & $\mathrm{x}$ & $\mathrm{x}$ & & & $\mathrm{x}$ & & & No \\
\hline Shu et al. (2011) & & $\mathrm{X}$ & $\mathrm{x}$ & $\mathrm{x}$ & & & & $\mathrm{x}$ & & $\mathrm{x}$ & Yes \\
\hline Wright et al. (2019) & & & & $\mathrm{x}$ & $\mathrm{x}$ & $\mathrm{x}$ & & $\mathrm{x}$ & & & Yes \\
\hline \multicolumn{12}{|l|}{ Cohort (04) } \\
\hline Alshabanat et al. (2017) & & & & $\mathrm{x}$ & $\mathrm{x}$ & & & $\mathrm{x}$ & $\mathrm{X}$ & & Yes \\
\hline Bae-Shaaw et al. (2020) & & & $\mathrm{x}$ & $\mathrm{x}$ & & & $\mathrm{x}$ & $\mathrm{x}$ & & & Yes \\
\hline Baker et al. (2018) & & & $\mathrm{x}$ & & $\mathrm{x}$ & & & & & & No \\
\hline Bilchick et al. (2019) & & & & $\mathrm{x}$ & $\mathrm{x}$ & & $\mathrm{x}$ & $\mathrm{x}$ & $\mathrm{X}$ & & Yes \\
\hline Christy et al. (2016) & & & $\mathrm{x}$ & $\mathrm{x}$ & $\mathrm{x}$ & $\mathrm{x}$ & $\mathrm{x}$ & $\mathrm{x}$ & & & No \\
\hline Howie-Esquivel et al. (2015) & & & $\mathrm{x}$ & $\mathrm{x}$ & & & $\mathrm{x}$ & $\mathrm{x}$ & & & Yes \\
\hline Kwan et al. (2015) & & & $\mathrm{x}$ & $\mathrm{x}$ & & & $\mathrm{x}$ & $\mathrm{x}$ & & & No \\
\hline Lee et al. (2019) & & & $\mathrm{x}$ & & $\mathrm{x}$ & $\mathrm{x}$ & & & & & No \\
\hline Murphy et al. (2019) & & & $\mathrm{x}$ & & & $\mathrm{x}$ & $\mathrm{x}$ & & & & Yes \\
\hline Otsuka et al. (2019) & & $\mathrm{X}$ & & $\mathrm{x}$ & $\mathrm{x}$ & & $\mathrm{x}$ & $\mathrm{x}$ & & & Yes \\
\hline Patel et al. (2019) & & & & $\mathrm{x}$ & & & & $\mathrm{x}$ & & & No \\
\hline Shcherbakova et al. (2016) & & & & $\mathrm{x}$ & $\mathrm{x}$ & & & & $\mathrm{X}$ & & No \\
\hline Shull et al. (2018) & & & $\mathrm{x}$ & $\mathrm{x}$ & $\mathrm{x}$ & & & $\mathrm{x}$ & $\mathrm{X}$ & & Yes \\
\hline Stranges et al. (2015) & & $\mathrm{X}$ & $\mathrm{x}$ & $\mathrm{x}$ & $\mathrm{x}$ & $\mathrm{x}$ & $\mathrm{x}$ & $\mathrm{x}$ & & & No \\
\hline Takahashi et al. (2016) & & $\mathrm{X}$ & $\mathrm{x}$ & $\mathrm{x}$ & $\mathrm{x}$ & $\mathrm{x}$ & & $\mathrm{x}$ & $\mathrm{X}$ & & Yes \\
\hline
\end{tabular}




\begin{tabular}{|c|c|c|c|c|c|c|c|c|c|c|c|}
\hline Truong et al. (2015) & & & $\mathrm{x}$ & $\mathrm{x}$ & $\mathrm{x}$ & & & $\mathrm{x}$ & $\mathrm{X}$ & & Yes \\
\hline Wee et al. (2014) & & $\mathrm{X}$ & $\mathrm{x}$ & & & $\mathrm{x}$ & & $\mathrm{x}$ & $\mathrm{X}$ & & Yes \\
\hline Yang et al. (2017) & & & & $\mathrm{x}$ & & & & $\mathrm{x}$ & & & No \\
\hline Zemaitis et al. (2016) & & & $\mathrm{x}$ & $\mathrm{x}$ & $\mathrm{x}$ & & & $\mathrm{x}$ & & & Yes \\
\hline \multicolumn{12}{|c|}{$\begin{array}{l}\text { Retrospective and descriptive } \\
\text { (LE 04) }\end{array}$} \\
\hline Chava et al. (2019) & & & $\mathrm{x}$ & & & & & & & & Yes \\
\hline Costantino et al. (2013) & & & & $\mathrm{x}$ & & $\mathrm{x}$ & & $\mathrm{x}$ & & & Yes \\
\hline Farrell et al. (2015) & & & & $\mathrm{x}$ & & $\mathrm{x}$ & & $\mathrm{x}$ & & & Yes \\
\hline Singh et al. (2019) & $\mathrm{x}$ & & & & $\mathrm{x}$ & & & & & & No \\
\hline Wiegmann et al. (2019) & & & $\mathrm{x}$ & $\mathrm{x}$ & $\mathrm{x}$ & & $\mathrm{x}$ & & & & Yes \\
\hline \multicolumn{12}{|l|}{ Observational (LE 04) } \\
\hline Patel et al. (2016) & & & & & & & & & & $\mathrm{x}$ & No \\
\hline Stewart et al. (2015) & & & & & & $\mathrm{x}$ & & $\mathrm{x}$ & & & No \\
\hline \multicolumn{12}{|l|}{ Case-control (LE 04) } \\
\hline Clarkson et al. (2017) & & & $\mathrm{x}$ & $\mathrm{x}$ & & & & & & $\mathrm{x}$ & Yes \\
\hline
\end{tabular}

*Statitiscally significant differences.

IRR: Identification of the Readmission Risk. DP: Discharge Planning. EHH: Education in Health during Hospitalization. EHD: Education in Health after Discharge. MR: Medication Reconciliation. CHS: Communication with Health Services. OFD: Outpatient Follow-up after Discharge. PCD: Phone Contact after Discharge. PHV: Post-discharge Home Visit. LE: level of evidence. Sources: Authors.

\section{Discussion}

The use of strategies to reduce the number of readmissions within 30 days stood out in the international literature, whereas it is still not well explored nationally in Brazil. A greater number of publications were found in the United States, particularly after 2013. The greatest number of research studies on reducing hospital readmissions in the United States can be justified by the implementation of the Hospital Readmissions Reduction Program in 2012, when the federal government started to apply financial penalties to hospitals with excessive readmission rates (Costantino et al., 2013). Only one study (Bonetti et al., 2018) was identified in Brazil, which indicates that this topic has not been well explored in this county.

Most of the interventions to reduce the number of hospital readmissions within 30 days were conducted in populations of seniors and in patients with heart disease and/or chronic respiratory disease. Individuals aged 60 years old or more are vulnerable to readmissions (Neta et al., 2017). Among the main factors for readmissions within 30 days are number of chronic diseases, disease severity and risk of death. Therefore, patients with severe diseases and multiple chronic conditions should be prioritized in hospital care transition interventions to reduce the rate of unnecessary readmissions (Conner et al., 2020).

In this review, the interventions delivered to patients were varied and exerted different effects on the outcome of reduction in the number of readmissions within 30 days. The heterogeneity of the interventions and of the different methodological designs did not allow identifying the most effective components. Most of the research studies included were observational or quasi-experimental, and the randomized clinical trials corresponded to $26.8 \%$ of the sample. In a previously published systematic review, the authors also verified predominance of observational studies and identified that no intervention implemented in isolation was regularly associated with a reduction in the risk of readmissions within 30 days. The authors developed a taxonomy to categorize the interventions, which encompassed 12 activities. The pre-discharge interventions included education to the patient, medication reconciliation, discharge planning and scheduling of a follow-up appointment. The post-discharge interventions included follow-up phone calls, communication with health professionals, outpatient follow-up and post-discharge home visits, among others (Hansen et al., 2011). 
In this review it was verified that the most frequently implemented interventions were phone contact after discharge and education in health for patients and caregivers; identification of the readmission risk, discharge planning and post-discharge home visits were the least frequent interventions. This result presents similarities regarding some components of a systematic review with meta-analysis of care transition actions in surgical patients, which identified that the most frequently assessed interventions were phone follow-up and education to the patients. However, discharge planning and home visits were also more frequent (Jones et al., 2016), which differs from this study.

It was identified that the phone contact component was the most frequent intervention, corresponding to the results described in the literature (Hansen et al., 2011, Jones et al., 2016). Phone contacts allow identifying questions from patients and caregivers in the household context, defining priorities in home visits, and immediate interventions during the call (Weber et al., 2017).

The interventions with components related to health education during hospitalization (EHH) and after discharge (EHD) stand out. The strategies used in the studies reviewed may provide the opportunity to involve the patients, promote understanding and increase their self-care ability, thus improving the post-discharge outcomes. However, a study with surgical patients in Australia identified that many of them expressed dissatisfaction and insufficient understanding of the discharge guidelines, resulting in anxiety and stress due to insecurity in dealing with their recovery. There were reports of unclear instructions, given too hastily and not in a timely manner, not adapted to the individual needs, and with inappropriate post-discharge care recommendations (Kang et al., 2020). Therefore, the literature acknowledges that the activities aimed at the patients' education and promotion of self-management are fundamental for care transition, provided that the education plans are individualized, respecting the way how patients think and live in their sociocultural context and promoting their autonomy in shared decisionmaking processes (Lima et al., 2018).

Having a discharge plan is important for the implementation of self-care education. Discharge planning is a process that should begin at hospital admission and includes the development of a patient-centered plan, which must be periodically reviewed during hospitalization, ensuring that patients and caregivers understand and contribute to the decisions planned (Mennuni et al., 2016). A study on care transition actions in Latin America identified that the care plans contained lists of medications and instructions, social support for access to the health services, underlying diseases, warning signs and symptoms, nutritional care and clinical monitoring (Lima et al., 2018), actions similar to those observed in the articles included in this research. However, discharge planning was one of the least frequent components in the articles, which may be a routine practice, but not being carried out consistently in the interventions.

Although the Medication Reconciliation (MR) component is not one of the most frequent interventions in this review, it may be an effective tool for the management of medications. The main focus of this component is the patient's understanding about the drug regime, valuing detailed information of the indications, benefits, therapeutic goals, dosage, administration times, storage, duration of the therapies and possible drug-related adverse events. Most of the studies highlight the essential performance of pharmacists, nurses and health teams in the promotion of adherence to the medications and in the provision of medication reconciliation. However, a systematic review identified that medication reconciliation alone does not reduce the number of readmissions but, if combined with education for the patient, especially after discharge, it becomes a powerful tool to this end (Bach et al., 2019).

Post-discharge home visits, which are focused on adherence to the medications, adequate outpatient follow-up and monitoring of symptoms, were a component that occurred in less than $30 \%$ of the studies. Although home visits are time intensive with a higher cost, they have been described in the literature as an effective intervention to reduce the number of readmissions within 30 days among clinical (Hansen et al., 2011) and surgical (Jones et al., 2016) adult patients. 
The interventions analyzed in this study were predominantly conducted by a multi-professional team, pharmacists and nurses. The important performance of interprofessional teams in the care provided to the patients is highlighted. A study that assessed frail seniors evidenced that those who received integrated care with a interprofessional team attained a significant reduction in the number of unnecessary readmissions, as well as in the search for the emergency services (Di Pollina et al., 2017).

Technologies such as fax, email, message applications, phone calls, and printed reports were used in communication with health services in the community. The use of communication technologies can streamline and qualify the communication flows in health and increase collaboration between the hospital team and the post-discharge team. The study showed that followup during the first week after hospital discharge has been associated with lower readmission rates within 30 and 90 days. The patients who attended a primary care appointment within 7 days after discharge had a lower number of readmissions compared with those who did not attend any appointment or who had one within the subsequent weeks (Wiest et al., 2019).

The heterogeneity of the articles' methods is a limitation of this study. The method did not allow the identification of the actions that are more effective in reducing the number of hospital readmissions. Therefore, it is worth highlighting the need to conduct systematic reviews and meta-analyses with a focus on specific components or on bundling combinations of interventions to fill this gap.

\section{Conclusion}

This integrative review provided evidence that there is vast scientific knowledge in this area, especially in the United States, a country that applies financial penalties to hospitals with excessive readmission rates. The theme of interventions to reduce the number of hospital readmissions has not been the focus of studies and research in Brazil or in Latin America.

This review sought to synthesize the main interventions reported in the literature to reduce the number of hospital readmissions, although not able to recommend any practice over another. Several interventions performed in the research studies were identified, and the most frequent components were Phone Contact after Discharge, Education in Health after Discharge, and Education in Health during Hospitalization. It was found that the interventions were aimed at preparing the patients during hospitalization for returning to their homes with follow-up after discharge to reinforce the care plans and clarify doubts. Important to reduce hospital readmissions, is the implementation of combined interventions by the interprofessional team. The commitment of institutions and professionals enables interventions that change work routine, health promotion, prevention of health problems and recovery of health, with a focus that goes beyond treatment and clinical stabilization of patients. The results facilitate improvement in health practices with a focus on planned care transitions, resulting in benefits for patients, professionals and the health system.

Future research is needed to evaluate the effectiveness of specific components or on bundling combinations of interventions to reduce hospital readmission. We recommend studies with higher level of evidence, such as clinical trials, especially in Brazil and Latin America. Implementing evidence-informed practice might be challenging, though strategies to set priorities of which intervention to implement should consider opinions of stakeholders, including patients, health care providers, and hospital managers.

\section{Acknowledgments}

This study was funded by Fundação de Amparo a Pesquisa do Estado do Rio Grande do Sul (FAPERGS) (Process n. 19/2551-0001213-6) and by Conselho Nacional de Desenvolvimento Científico e Tecnológico (CNPq) (Process n. 433997/20184). 


\section{References}

Alshabanat, A., Otterstatter, M. C., Sin, D. D., Road, J., Rempel, C., Burns, J., .. \& FitzGerald, J. M. (2017). Impact of a COPD comprehensive case management program on hospital length of stay and readmission rates. International Journal of Chronic Obstructive Pulmonary Disease, 12, 961-971. https://doi.org/10.2147/COPD.S124385

Altfeld, S. J., Shier, G. E., Rooney, M., Johnson, T. J., Golden, R. L., Karavolos, K., ... \& Perry, A. J. (2013). Effects of an enhanced discharge planning intervention for hospitalized older adults: a randomized trial. Gerontologist, 53(3), 430-440.

Amarasingham, R., Patel, P. C., Toto, K., Nelson, L. L., Swanson, T. S., Moore, B. J., Xie, B., ... \& Halm, E. A. (2013). Allocating scarce resources in realtime to reduce heart failure readmissions: a prospective, controlled study. BMJ Quality \& Safety, 22(12), 998-1005. https://doi.org/10.1136/bmjqs-2013-001901

Auerbac, A. D., Kripalani, S., Vasilevskis, E. E., Sehgal, N., Lindenauer, P. K., Metlay, J. P., ... \& Schnipper JL. (2016). Preventability and causes of readmissions in a national cohort of general medicine patients. JAMA Internal Medicine, 176(4), 484-493.

Bach, Q. N., Peasah, S. K., \& Barber, E. (2019). Review of the Role of the Pharmacist in Reducing Hospital Readmissions. Journal of Pharmacy Practice, 32(6), 617-624. https://doi.org/10.1177/0897190018765500

Bae-Shaaw, Y. H., Eom, H., Chun, R. F., \& Steven Fox, D. (2020). Real-world evidence on impact of a pharmacist-led transitional care program on 30- and 90day readmissions after acute care episodes. American Journal of Health-system Pharmacy, 77(7), 535-545. https://doi.org/10.1093/ajhp/zxaa012

Baker, M., Bell, C. M., Xiong, W., Etchells, E., Rossos, P. G., Shojania, K. G., ... \& Fernandes, O. (2018). Do Combined Pharmacist and Prescriber Efforts on Medication Reconciliation Reduce Postdischarge Patient Emergency Department Visits and Hospital Readmissions? Journal of Hospital Medicine, 13(3), 152157. https://doi.org/10.12788/jhm.2857

Balaban, R. B., Galbraith, A. A., Burns, M. E., Vialle-Valentin, C. E., Larochelle, M. R. \& Ross-Degnan, D. (2015). A patient navigator intervention to reduce hospital readmissions among high-risk safety-net patients: a randomized controlled trial. Journal of General Internal Medicine, 30(7), 907-915.

Bell, S. P., Schnipper, J. L., Goggins, K., Bian, A., Shintani, A., Roumie, C. L., .. \& Kripalani, S. (2016). Effect of pharmacist counseling intervention on health care utilization following hospital discharge: a randomized control trial. Journal of General Internal Medicine, 31(5), 470-477.

Benzo, R., Vickers, K., Novotny, P. J., Tucker, S., Hoult, J., Neuenfeldt, P., ... \& McEvoy, C. (2016). Health coaching and chronic obstructive pulmonary disease rehospitalization. a randomized study. American Journal of Respiratory and Critical Care Medicine, 194(6), 672-80.

Bhatt, S. P., Wells, J. M., Iyer, A. S., Kirkpatrick, D. P., Parekh, T. M., Leach, L. T., Anderson, E. M., ... \& Dransfield, M. T. (2017). Results of a Medicare Bundled Payments for Care Improvement Initiative for Chronic Obstructive Pulmonary Disease Readmissions. Annals of the American Thoracic Society, 14(5), 643-648. https://doi.org/10.1513/AnnalsATS.201610-775BC

Bilchick, K., Moss, T., Welch, T., Levy, W., Stukenborg, G., Lawlor, B. T., ... \& Mazimba, S. (2019). Improving Heart Failure Readmission Costs and Outcomes With a Hospital-to-Home Readmission Intervention Program. American Journal of Medical Quality: the official journal of the American College of Medical Quality, 34(2), 127-135. https://doi.org/10.1177/1062860618788436

Bonetti, A. F., Bagatim, B. Q., Mendes, A. M., Rotta, I., Reis, R. C., Fávero, M. L. D., ... \& Pontarolo, R. (2018). Impact of discharge medication counseling in the cardiology unit of a tertiary hospital in Brazil: a randomized controlled trial. Clinics, 73, e325.

Bowles, K. H., Chittams, J., Heil, E., Topaz, M., Rickard, K., Bhasker, M., ... \& Hanlon, A. L. (2015). Successful electronic implementation of discharge referral decision support has a positive impact on 30- and 60-day readmissions. Research in Nursing \& Health, 38(2), 102-114. https://doi.org/10.1002/nur.21643

Budiman, T., Snodgrass, K., \& Komatsu Chang, A. (2016). Evaluation of Pharmacist Medication Education and Post-discharge Follow-up in Reducing Readmissions in Patients With ST-Segment Elevation Myocardial Infarction (STEMI). The Annals of Pharmacotherapy, 50(2), 118-124. https://doi.org/10.1177/1060028015620425

Chava, R., Karki, N., Ketlogetswe, K., \& Ayala, T. (2019). Multidisciplinary rounds in prevention of 30-day readmissions and decreasing length of stay in heart failure patients: A community hospital based retrospective study. Medicine, 98(27), e16233. https://doi.org/10.1097/MD.0000000000016233

Christy, S., Sin, B., \& Gim, S. (2016). Impact of an Integrated Pharmacy Transitions of Care Pilot Program in an Urban Hospital. Journal of Pharmacy Practice, 29(5), 490-494. https://doi.org/10.1177/0897190014568674

Clarkson, J. N., Schaffer, S. D., \& Clarkson, J. J. (2017). The Effect of an Interprofessional Heart Failure Education Program on Hospital Readmissions. Journal for Healthcare Quality: official publication of the National Association for Healthcare Quality, 39(2), 78-84. https://doi.org/10.1097/JHQ.0000000000000027

Conner, K.O., Meng, H., Marino, V. \& Boaz, T. L. (2020). Individual and organizational factors associated with hospital readmission rates: evidence from a U.S. national sample. Journal of Applied Gerontology, 39(10), 1153-1158.

Costantino, M. E., Frey, B., Hall, B., \& Painter, P. (2013). The influence of a postdischarge intervention on reducing hospital readmissions in a Medicare population. Population Health Management, 16(5), 310-316. https://doi.org/10.1089/pop.2012.0084

Davis, K. K., Mintzer, M., Himmelfarb, C. R. D., Hayat, M. J., Rotman, S. \& Allen, J. (2012). Targeted intervention improves knowledge but not self-care or readmissions in heart failure patients with mild cognitive impairment. European Journal of Heart Failure, 14(9), 1041-1049.

Dedhia, P., Kravet, S., Bulger, J., Hinson, T., Sridharan, A., Kolodner, K., ... \& Howell, E. (2009). A quality improvement intervention to facilitate the transition of older adults from three hospitals back to their homes. Journal of the American Geriatrics Society, 57(9), 1540-1546. https://doi.org/10.1111/j.15325415.2009.02430.x 
Research, Society and Development, v. 11, n. 2, e2011225273, 2022

(CC BY 4.0) | ISSN 2525-3409 | DOI: http://dx.doi.org/10.33448/rsd-v11i2.25273

Deek, H., Chang, S., Newton, P. J., Noureddine, S., Inglis, S. C., Arab, G. A., ... \& Davidson, P. M. (2017). An evaluation of involving family caregivers in the self-care of heart failure patients on hospital readmission: randomised controlled trial (the FAMILY study). International Journal of Nursing Studies, 75, 101111.

Dhalla, I. A., O'Brien, T., Morra, D., Thorpe, K. E., Wong, B. M., Mehta, R., ... \& Laupacis, A. (2014). Effect of a postdischarge virtual ward on readmission or death for high-risk patients: a randomized clinical trial. JAMA, 312(13), 1305-1312.

Di Pollina, L., Guessous, I., Petoud, V., Combescure, C., Buchs, B., Schaller, P., ... \& Gaspoz, J. M. (2017). Integrated care at home reduces unnecessary hospitalizations of community-dwelling frail older adults: a prospective controlled trial. BMC geriatrics, 17(1), 53. https://doi.org/10.1186/s12877-017-0449-9

Farrell, T. W., Tomoaia-Cotisel, A., Scammon, D. L., Brunisholz, K., Kim, J., Day, J., ... \& Magill, M. K. (2015). Impact of an integrated transition management program in primary care on hospital readmissions. Journal for Healthcare Quality : official publication of the National Association for Healthcare Quality, 37(1), 81-92. https://doi.org/10.1097/01.JHQ.0000460119.68190.98

Farris, K. B., Carter, B. L., Xu, Y., Dawson, J. D., Shelsky, C., Weetman, D. B., Kaboli, P. J., ... \& Brooks, J. M. (2014). Effect of a care transition intervention by pharmacists: an RCT. BMC Health Services Research, 14, 406. https://doi.org/10.1186/1472-6963-14-406

Fischer, C., Anema, H. A. \& Klazinga, N. S. (2012). The validity of indicators for assessing quality of care: a review of the European literature on hospital readmission rate. European Journal of Public Health, 22(4), 484-491.

Garnier, A., Rouiller, N., Gachoud, D., Nachar, C., Voirol, P., Griesser, A. C., ... \& Lamy, O. (2018). Effectiveness of a transition plan at discharge of patients hospitalized with heart failure: a before-and-after study. ESC Heart Failure, 5(4), 657-667. https://doi.org/10.1002/ehf2.12295

Graabaek, T., Hedegaard, U., Christensen, M. B., Clemmensen, M. H., Knudsen, T., \& Aagaard, L. (2019). Effect of a medicines management model on medication-related readmissions in older patients admitted to a medical acute admission unit-A randomized controlled trial. Journal of Evaluation in Clinical Practice, 25(1), 88-96. https://doi.org/10.1111/jep.13013

Graham, J., Tomcavage, J., Salek, D., Sciandra, J., Davis, D. E., \& Stewart, W. F. (2012). Postdischarge monitoring using interactive voice response system reduces 30-day readmission rates in a case-managed Medicare population. Medical Care, 50(1), 50-57. https://doi.org/10.1097/MLR.0b013e318229433e

Haag, J. D., Davis, A. Z., Hoel, R. W., Armon, J. J., Odell, L. J., Dierkhising, R. A., \& Takahashi, P. Y. (2016). Impact of Pharmacist-Provided Medication Therapy Management on Healthcare Quality and Utilization in Recently Discharged Elderly Patients. American Health \& Drug Benefits, 9(5), $259-268$.

Hansen, L. O., Young, R. S., Hinami, K., Leung, A., \& Williams, M. V. (2011). Interventions to reduce 30-day rehospitalization: a systematic review. Annals of Internal Medicine, 155(8), 520-528. https://doi.org/10.7326/0003-4819-155-8-201110180-00008

Hawes, E. M., Maxwell, W. D., White, S. F., Mangun, J., \& Lin, F. C. (2014). Impact of an outpatient pharmacist intervention on medication discrepancies and health care resource utilization in posthospitalization care transitions. Journal of Primary Care \& Community Health, 5(1), 14-18. https://doi.org/10.1177/2150131913502489

Howie-Esquivel, J., Carroll, M., Brinker, E., Kao, H., Pantilat, S., Rago, K., \& De Marco, T. (2015). A Strategy to Reduce Heart Failure Readmissions and Inpatient Costs. Cardiology Research, 6(1), 201-208. https://doi.org/10.14740/cr384w

Huynh, Q. L., Whitmore, K., Negishi, K., Marwick, T. H. \& ETHELRED Investigators. (2019). Influence of risk on reduction of readmission and death by disease management programs in heart failure. Journal of Cardiac Failure, 25(5), 330-339.

Jennings, J. H., Thavarajah, K., Mendez, M. P., Eichenhorn, M., Kvale, P., \& Yessayan, L. (2015). Predischarge bundle for patients with acute exacerbations of COPD to reduce readmissions and ED visits: a randomized controlled trial. Chest, 147(5), 1227-1234. https://doi.org/10.1378/chest.14-1123

Johnson-Warrington, V., Rees, K., Gelder, C., Morgan, M. D., \& Singh, S. J. (2016). Can a supported self-management program for COPD upon hospital discharge reduce readmissions? A randomized controlled trial. International Journal of Chronic Obstructive Pulmonary Disease, 11, 1161-1169. https://doi.org/10.2147/COPD.S91253

Johnson, A. E., Winner, L., Simmons, T., Eid, S. M., Hody, R., Sampedro, A., ... \& Parakh, K. (2016). Using Innovative Methodologies From Technology and Manufacturing Companies to Reduce Heart Failure Readmissions. American Journal of Medical Quality: the official journal of the American College of Medical Quality, 31(3), 272-278. https://doi.org/10.1177/1062860614562627

Jones, C. E., Hollis, R. H., Wahl, T. S., Oriel, B. S., Itani, K. M., Morris, M. S., \& Hawn, M. T. (2016). Transitional care interventions and hospital readmissions in surgical populations: a systematic review. American Journal of Surgery, 212(2), 327-335. https://doi.org/10.1016/j.amjsurg.2016.04.004

Kang, E., Gillespie, B. M., Tobiano, G., \& Chaboyer, W. (2020). General surgical patients' experience of hospital discharge education: A qualitative study. Journal of Clinical Nursing, 29(1-2), e1-e10. https://doi.org/10.1111/jocn.15057

Kripalani, S., Chen, G., Ciampa, P., Theobald, C., Cao, A., McBride, M., ...\& Speroff, T. (2019). A transition care coordinator model reduces hospital readmissions and costs. Contemporary Clinical Trials, 81, 55-61. https://doi.org/10.1016/j.cct.2019.04.014

Kwan, J. L., Morgan, M. W., Stewart, T. E., \& Bell, C. M. (2015). Impact of an innovative inpatient patient navigator program on length of stay and 30-day readmission. Journal of Hospital Medicine, 10(12), 799-803. https://doi.org/10.1002/jhm.2442

Lee, K. H., Low, L. L., Allen, J., Barbier, S., Ng, L. B., Ng, M. J., ... \& Tan, S. Y. (2015). Transitional care for the highest risk patients: findings of a randomised control study. International Journal of Integrated Care, 15, e039. https://doi.org/10.5334/ijic.2003

Lee, R., Malfair, S., Schneider, J., Sidhu, S., Lang, C., Bredenkamp, N., .. \& \& Virani, A. (2019). Evaluation of Pharmacist Intervention on Discharge Medication Reconciliation. The Canadian Journal of Hospital Pharmacy, 72(2), 111-118. 
Research, Society and Development, v. 11, n. 2, e2011225273, 2022

(CC BY 4.0) | ISSN 2525-3409 | DOI: http://dx.doi.org/10.33448/rsd-v11i2.25273

Lima, M. A. D. S., Magalhães, A. M. M., Oelke, N. D., Marques, G. Q., Lorenzini, E., Weber, L. A. F. \& Fan, I. (2018). Care transition strategies in Latin American countries: an integrative review. Revista Gaúcha de Enfermagem, 39, e20180119.

Linden, A., \& Butterworth, S. (2014). A comprehensive hospital-based intervention to reduce readmissions for chronically ill patients: a randomized controlled trial. The American Journal of Managed Care, 20(10), 783-792.

Low, L. L., Tan, S. Y., Ng, M. J., Tay, W. Y., Ng, L. B., Balasubramaniam, K., ... \& Lee, K. H. (2017). Applying the Integrated Practice Unit Concept to a Modified Virtual Ward Model of Care for Patients at Highest Risk of Readmission: A Randomized Controlled Trial. PloS One, 12(1), e0168757. https://doi.org/10.1371/journal.pone.0168757

Melnyk, B. M. \& Fineout-Overholt, E. (2015). Evidence-based practice in nursing \& healthcare: a guide to best practice. (3rd ed.). Philadelphia: Wolters Kluwer Health.

Mennuni, M., Gulizia, M. M., Alunni, G., Amico, A. F., Bovenzi, F. M., Caporale, R., ... \& Zuin, G. (2016). Position paper ANMCO: Gestione della dimissione ospedaliera [ANMCO Position paper: Hospital discharge planning]. Giornale italiano di cardiologia, 17(9), 657-686. https://doi.org/10.1714/2448.25660

Morales, B. P., Planas, R., Bartoli, R., Morillas, R. M., Sala, M., Casas, I., ... \& Masnou, H. (2018). HEPACONTROL. A program that reduces early readmissions, mortality at 60 days, and healthcare costs in decompensated cirrhosis. Digestive and Liver Disease: official journal of the Italian Society of Gastroenterology and the Italian Association for the Study of the Liver, 50(1), 76-83. https://doi.org/10.1016/j.dld.2017.08.024

Murphy, J. A., Schroeder, M. N., Rarus, R. E., Yakubu, I., McKee, S., \& Martin, S. J. (2019). Implementation of a Cardiac Transitions of Care Pilot Program: A Prospective Study of Inpatient and Outpatient Clinical Pharmacy Services for Patients With Heart Failure Exacerbation or Acute Myocardial Infarction Journal of Pharmacy Practice, 32(1), 68-76. https://doi.org/10.1177/0897190017743129

Murphy, J. A., Schroeder, M. N., Ridner, A. T., Gregory, M. E., Whitner, J. B., \& Hackett, S. G. (2020). Impact of a Pharmacy-Initiated Inpatient Diabetes Patient Education Program on 30-Day Readmission Rates. Journal of Pharmacy Practice, 33(6), 754-759. https://doi.org/10.1177/0897190019833217

Neta, A. C. F., Jorge, A. O., Viudes, M. A. A., Silva, K. L., Orlando, C. R. P., Almeida, L. H., Cruz, M. C. S. ... \& Costa, J. M. (2017). O perfil das reinternações de um hospital de ensino de Belo Horizonte no ano de 2013. Revista Salusvita, 36(2), 443-461.

Odeh, M., Scullin, C., Fleming, G., Scott, M. G., Horne, R., \& McElnay, J. C. (2019). Ensuring continuity of patient care across the healthcare interface: Telephone follow-up post-hospitalization. British Journal of Clinical Pharmacology, 85(3), 616-625. https://doi.org/10.1111/bcp.13839

Ohuabunwa, U., Jordan, Q., Shah, S., Fost, M., \& Flacker, J. (2013). Implementation of a care transitions model for low-income older adults: a high-risk, vulnerable population. Journal of the American Geriatrics Society, 61(6), 987-992. https://doi.org/10.1111/jgs.12276

Oscalices, M. I. L., Okuno, M. F. P., Lopes, M. C. B. T., Campanharo, C. R. V. \& Batista, R. E. A. (2019). Discharge guidance and telephone follow-up in the therapeutic adherence of heart failure: randomized clinical trial. Revista Latino-Americana de Enfermagem, 27, e3159. https://doi.org/10.1590/15188345.2484 .3159

Otsuka, S., Smith, J. N., Pontiggia, L., Patel, R. V., Day, S. C., \& Grande, D. T. (2019). Impact of an interprofessional transition of care service on 30-day hospital reutilizations. Journal of Interprofessional Care, 33(1), 32-37. https://doi.org/10.1080/13561820.2018.1513466

Patel, A., Dodd, M. A., D'Angio, R., Hellinga, R., Ahmed, A., Vanderwoude, M., \& Sarangarm, P. (2019). Impact of discharge medication bedside delivery service on hospital reutilization. American Journal of Health-system Pharmacy: AJHP: official journal of the American Society of Health-System Pharmacists, 76(23), 1951-1957. https://doi.org/10.1093/ajhp/zxz197

Patel, M. S., Patel, N., Small, D. S., Rosin, R., Rohrbach, J. I., Stromberg, N., ... \& Asch, D. A. (2016). Change In Length of Stay and Readmissions among Hospitalized Medical Patients after Inpatient Medicine Service Adoption of Mobile Secure Text Messaging. Journal of General Internal Medicine, 31(8), 863870. https://doi.org/10.1007/s11606-016-3673-7

Rafferty, A., Denslow, S., \& Michalets, E. L. (2016). Pharmacist-Provided Medication Management in Interdisciplinary Transitions in a Community Hospital (PMIT). The Annals of Pharmacotherapy, 50(8), 649-655. https://doi.org/10.1177/1060028016653139

Riegel, B., Creber, R. M., Hill, J., Chittams, J., \& Hoke, L. (2016). Effectiveness of Motivational Interviewing in Decreasing Hospital Readmission in Adults With Heart Failure and Multimorbidity. Clinical Nursing Research, 25(4), 362-377. https://doi.org/10.1177/1054773815623252

Sales, V. L., Ashraf, M. S., Lella, L. K., Huang, J., Bhumireddy, G., Lefkowitz, L., ...\& Heitner, J. F. (2013). Utilization of trained volunteers decreases 30-day readmissions for heart failure. Journal of Cardiac Failure, 19(12), 842-850. https://doi.org/10.1016/j.cardfail.2013.10.008

Sarangarm, P., London, M. S., Snowden, S. S., Dilworth, T. J., Koselke, L. R., Sanchez, C. O., ...\& Ray, G. (2013). Impact of pharmacist discharge medication therapy counseling and disease state education: Pharmacist Assisting at Routine Medical Discharge (project PhARMD). American Journal of Medical Quality: the official journal of the American College of Medical Quality, 28(4), 292-300. https://doi.org/10.1177/1062860612461169

Shcherbakova, N., \& Tereso, G. (2016). Clinical pharmacist home visits and 30-day readmissions in Medicare Advantage beneficiaries. Journal of Evaluation in Clinical Practice, 22(3), 363-368. https://doi.org/10.1111/jep.12495

Shu, C. C., Hsu, N. C., Lin, Y. F., Wang, J. Y., Lin, J. W., \& Ko, W. J. (2011). Integrated postdischarge transitional care in a hospitalist system to improve discharge outcome: an experimental study. BMC Medicine, 9 , 96. https://doi.org/10.1186/1741-7015-9-96

Shull, M. T., Braitman, L. E., Stites, S. D., DeLuca, A., \& Hauser, D. (2018). Effects of a pharmacist-driven intervention program on hospital readmissions. American Journal of Health-system Pharmacy: AJHP: official journal of the American Society of Health-System Pharmacists, 75(9), e221-e230. https://doi.org/10.2146/ajhp170287

Singh, D., Fahim, G., Ghin, H. L., \& Mathis, S. (2021). Effects of Pharmacist-Conducted Medication Reconciliation at Discharge on 30-Day Readmission Rates of Patients With Chronic Obstructive Pulmonary Disease. Journal of Pharmacy Practice, 34(3), 354-359. https://doi.org/10.1177/0897190019867241 
Smith, K. J., Handler, S. M., Kapoor, W. N., Martich, G. D., Reddy, V. K., \& Clark, S. (2016). Automated Communication Tools and Computer-Based Medication Reconciliation to Decrease Hospital Discharge Medication Errors. American Journal of Medical Quality: the official journal of the American College of Medical Quality, 31(4), 315-322. https://doi.org/10.1177/1062860615574327

Soong, C., Kurabi, B., Wells, D., Caines, L., Morgan, M. W., Ramsden, R., \& Bell, C. M. (2014). Do post discharge phone calls improve care transitions? A cluster-randomized trial. PloS One, 9(11), e112230. https://doi.org/10.1371/journal.pone.0112230

Souza, D. K. \& Peixoto, S. V. (2017). Descriptive study on the evolution of hospitalization costs for ambulatory care sensitive conditions in Brazil, 2000-2013. Revista Epidemiologia e Serviços de Saúde, 26(2), 285-294. https://doi.org/10.5123/s1679-49742017000200006

Stewart, S. A., Worth, L., \& Burton, C. (2015). Evaluating a Telehealth Follow-up Program for Cardiology Patients Using Administrative Data. Studies in Health Technology and Informatics, 209, 156-161.

Stranges, P. M., Marshall, V. D., Walker, P. C., Hall, K. E., Griffith, D. K., \& Remington, T. (2015). A multidisciplinary intervention for reducing readmissions among older adults in a patient-centered medical home. The American Journal of Managed Care, 21(2), 106-113.

Takahashi, P. Y., Naessens, J. M., Peterson, S. M., Rahman, P. A., Shah, N. D., Finnie, D. M., Weymiller, A. J., Thorsteinsdottir, B., \& Hanson, G. J. (2016). Short-term and long-term effectiveness of a post-hospital care transitions program in an older, medically complex population. Healthcare (Amsterdam, Netherlands), 4(1), 30-35. https://doi.org/10.1016/j.hjdsi.2015.06.006

Tavares, M. G., Tedesco-Silva Junior, H. \& Pestana, J. O. M. (2020). Readmissão hospitalar precoce no transplante renal: artigo de revisão. Brazilian Journal of Nephrology, 42(2), 231-237. https://doi.org/10.1590/2175-8239-JBN-2019-0089

Thygesen, L. C., Fokdal, S., Gjørup, T., Taylor, R. S., Zwisler, A. D., \& Prevention of Early Readmission Research Group (2015). Can municipality-based postdischarge follow-up visits including a general practitioner reduce early readmission among the fragile elderly (65+ years old)? A randomized controlled trial. Scandinavian Journal of Primary Health Care, 33(2), 65-73. https://doi.org/10.3109/02813432.2015.1041831

Truong, J. T., \& Backes, A. C. (2015). The impact of a Continuum of Care Resident Pharmacist on heart failure readmissions and discharge instructions at a community hospital. SAGE Open Medicine, 3, 2050312115577986. https://doi.org/10.1177/2050312115577986

Verhaegh, K. J., Buurman, B. M., Veenboer, G. C., de Rooij, S. E., \& Geerlings, S. E. (2014). The implementation of a comprehensive discharge bundle to improve the discharge process: a quasi-experimental study. The Netherlands Journal of Medicine, 72(6), 318-325.

Voss, R., Gardner, R., Baier, R., Butterfield, K., Lehrman, S., \& Gravenstein, S. (2011). The care transitions intervention: translating from efficacy to effectiveness. Archives of Internal Medicine, 171(14), 1232-1237. https://doi.org/10.1001/archinternmed.2011.278

Walker, P. C., Bernstein, S. J., Jones, J. N., Piersma, J., Kim, H. W., Regal, R. E., ... \& Flanders, S. A. (2009). Impact of a pharmacist-facilitated hospital discharge program: a quasi-experimental study. Archives of Internal Medicine, 169(21), 2003-2010. https://doi.org/10.1001/archinternmed.2009.398

Weber, L. A. F., Lima, M. A. D. S. \& Acosta, A. M. (2019). Quality of care transition and its association with hospital readmission. Aquichan, 19(4), e1945. https://doi.org/10.5294/aqui.2019.19.4.5

Weber, L., Lima, M., Acosta, A., \& Marques, G. (2017). Transição do Cuidado do Hospital para o Domicílio: Revisão Integrativa. Cogitare Enfermagem, 22(3). http://dx.doi.org/10.5380/ce.v22i3.47615

Wee, S. L., Loke, C. K., Liang, C., Ganesan, G., Wong, L. M., \& Cheah, J. (2014). Effectiveness of a national transitional care program in reducing acute care use. Journal of the American Geriatrics Society, 62(4), 747-753. https://doi.org/10.1111/jgs.12750

Whittemore, R. \& Knafl, K. (2005). The integrative review: updated methodology. Journal of Advanced Nursing, 52(5), 546-553. https://doi.org/10.1111/j.13652648.2005.03621.x

Wiegmann, L. E., Belisle, M. S., Alvarez, K. S. \& Kale, N. J. (2020). Aiming beyond: a pharmacist impact on 90-day readmissions and clinical outcomes within a family medicine service. Journal of Pharmacy Practice, 33(6), 738-744. https://doi.org/10.1177/0897190019825970

Wiest, D., Yang, Q., Wilson, C., \& Dravid, N. (2019). Outcomes of a Citywide Campaign to Reduce Medicaid Hospital Readmissions With Connection to Primary Care Within 7 Days of Hospital Discharge. JAMA Network Open, 2(1), e187369. https://doi.org/10.1001/jamanetworkopen.2018.7369

Wright, E. A., Graham, J. H., Maeng, D., Tusing, L., Zaleski, L., Martin, R., ...\& Parry, D. T. (2019). Reductions in 30-day readmission, mortality, and costs with inpatient-to-community pharmacist follow-up. Journal of the American Pharmacists Association: JAPhA, 59(2), 178-186. https://doi.org/10.1016/j.japh.2018.11.005

Xiang, X., Zuverink, A., Rosenberg, W., \& Mahmoudi, E. (2019). Social work-based transitional care intervention for super utilizers of medical care: a retrospective analysis of the bridge model for super utilizers. Social Work in Health Care, 58(1), 126-141. https://doi.org/10.1080/00981389.2018.1547345

Yang S. (2017). Impact of pharmacist-led medication management in care transitions. BMC Health Services Research, 17(1), 722. https://doi.org/10.1186/s12913-017-2684-3

Zemaitis, C. T., Morris, G., Cabie, M., Abdelghany, O., \& Lee, L. (2016). Reducing Readmission at an Academic Medical Center: Results of a PharmacyFacilitated Discharge Counseling and Medication Reconciliation Program. Hospital Pharmacy, 51(6), 468-473. https://doi.org/10.1310/hpj5106-468 